\title{
Panará: Identificação linguística dos Kren- Akarore com os Cayapó do Sul
}

\author{
Aryon Dall'Igna Rodrigues \\ Luciana Gonçalves Dourado
}

Na primeira metade do século XIX os naturalistas J. E. Phi e A. de SaintHilaire colheram pequenas listas de palavras da boca dos índios aldeados em São José de Mossâmades, Goiás, e conhecidos desde o século anterior pelo nome de Cayapó, melhor especificado já no século passado como Cayapó do Sul para distingui-los dos Cayapó do norte de Goiás e do Pará. Em 1894 P. Ehrenreich publicou duas novas listas de palavras, uma colhida por Nehring e outra por Kupfer, ambas dos Cayapó do Sul que, em meados do século passado, estavam aldeados em Santana do Parnaíba (na confluência dos rios Grande e Parnaíba). Recentemente Heelas (1979) e Schwartzman (1987), baseados em algum conhecimento da língua dos Kren-akerore do rio Peixoto de Azevedo, a oeste do alto Xingu, e em inspeção às listas de Pohl e Saint-Hilaire, assim como em consideração de outros elementos culturais, levantaram a hipótese de uma particular afinidade entre os atuais Kren-akarore e os antigos Cayapó do Sul. Com a documentação e análise sistemática da língua Kren-Akarore por Dourado a partir de 1989 (Dourado 199), verificou-se que estes índios se autodenominam Panará, nome que coincide com a palavra Panariá, que SaintHilaire registrou como significando "índios", e que realmente tanto as listas deste autor, como as de Phil, de Kupfer e de Nehring registram ou a mesma língua, ou leves variantes dialetais da mesma. Agora, em 1992, Odair Giraldin, que vem fazendo um levantamento sistemático de documentação histórica sobre os Cayapó do Sul, encontrou no Instituto Histórico e Geográfico Brasileiro, no Rio de Janeiro, um manuscrito intitulado "Cayapó e panará" e datado de 1918, de autoria de Alexandre de Souza Barbosa, então residente em Uberaba. Nesse momento, Barbosa informou que encontrou em 1911, "junto á confluência do rio Grande e Paranyba, indios da aldeia de Agua Vermelha, que se chamavam panarás" e que, "em prazo infelizmente curto colligi os elementos de um vocabulário de sua língua”. O vocabulário de Barbosa é 
de grande amplitude, com cerca de 700 palavras, algumas frases soltas e um texto. Sua transcrição é qualitativamente superior às demais, o que se verifica pela discriminação de detalhes fonológicos que o registro do Panará atual tem revelado. Usa explicitamente o símbolo â para a vogal média central não arredondada e y para a alta central não arredondada (esta aliás ele identifica equivocadamente com a alta superior arredondada do francês): sem explicitar, emprega também com frequência o símbolo ù para a mesma vogal alta. $\mathrm{O}$ cotejo abaixo mostra como se identificam o atual Panará ("Kren-akarore") (Dourado 1990 e manuscritos) e o Panará de Barbosa (1918 [1911]) e como lhes correspondem os registros de 1819 de Pohl (1832) e Saint-Hilaire (184-).

$\begin{array}{lccccccccc} & \text { doce } & \text { mole } & \text { velho } & \text { roça } & \text { milho } & \text { amendoim } & \text { mão } & \text { chuva } & \text { folha } \\ \text { D. } & \text { sisí } & \text { pepéti } & \text { toputũ } & \text { puu } & \text { mõsí } & \text { sətí } & \text { sikiá } & \text { ĩtá } & \text { pərasó } \\ \text { B. } & \text { cici } & \text { pépét } & \text { taputúm } & \text { pu } & \text { môsý } & \text { sâti } & \text { cykiá intá } & \text { poraçô } \\ \text { P. } & - & - & - & - & \text { muschiú } & - & - & \text { intá } & - \\ \text { S. } & - & - & - & - & - & - & \text { chicria } & - & \text { parachó }\end{array}$

criança olho cabelo dente nariz peixe veado terra céu água D. prĩará ĩto ĩkĩ suá sakre tépi ĩpó ký́pa pukuá ĩko B. prĩaará intó îkin çuá çakré tép impó kypa pukuá inkô P. itpe-pri - $\quad-\quad c_{1} \quad-\quad-\quad$ tepu inpó cupá putka S. - intó iquim chuá chacaré tépo impó cúpa - incó

Conclui-se que a língua Panará de Barbosa, apesar de falada em 1911 no oeste de Minas Gerais, é a mesma dos Panará atuais, que em 1972 viviam no rio Peixoto de Azevedo, a oeste do alto Xingu, ao passo que a língua registrada por Pohl e Saint-Hilaire em 1819 em São José de Mossâmedes, Goiás, também é a mesma, mas possivelmente uma leve variante dialetal. Certamente faz-se necessário um estudo mais detalhado dos dados agora disponíveis. 